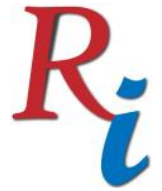

Asia Proceedings of Social Sciences

(APSS)

www.readersinsight.net/APSS

\title{
DETERMINANTS OF COMPETITIVE ADVANTAGE FOR SMALL AND MEDIUM ENTERPRISES IN DEVELOPING ECONOMIES: CAPABILITIES-BASED PERSPECTIVE
}

\section{Yakubu Salisu*}

Department of Business Administration

Yobe State University Damaturu, Yobe State

Nigeria

\section{Lily Julienti Abu Bakar}

School of Business Management, College of Business Universiti Utara Malaysia, Sintok Kedah Darul Aman Malaysia

*Corrosponding author's Email: ysalisu76@gmail.com

Peer-review under responsibility of $3^{\text {rd }}$ Asia International Multidisciplanry Conference 2019 editorial board (http://www.utm.my/asia/our-team/) (C) 2019 Published by Readers Insight Publisher, lat 306 Savoy Residencia, Block 3 F11/1,44000 Islamabad. Pakistan, info@ readersinsight.net This is an open access article under the CC BY-NC-ND license (http://creativecommons.org/licenses/by-nc-nd/4.0/). 


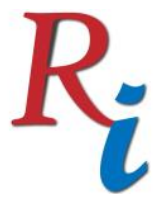

Asia Proceedings of Social Sciences

(APSS)

www.readersinsight.net/APSS

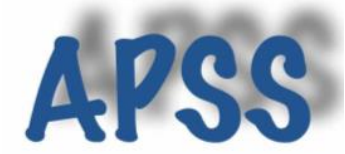

\section{I n t rod u c t i o n}

Small and medium enterprises (SMEs) in developing economies nowadays experiences strong competitions both locally and at the global markets. Consequently, Hall and Wagner, (2012) demonstrated the needs for an analysis of specific strategic capabilities required for sustainable development of small businesses. Despite the interest stimulated by the works of numerous scholars (Ma, 2004, Teece, 1992), there have been limited researches that attempted to examine and demonstrated the factors influencing competitive advantage of SMEs in developing economies. Devlin and Ennew, (1997) advocated that market driven competition arena and source of competitive advantage are easily recognizable for particular market. This study conceptualized six capabilities as strategic capabilities which can efficiently enhance SMEs competitive advantage at local and international markets. The results from the comfirmatory factor analysis through Cronbach's alpha demonstrated the reliability of the items measuring; innovation capability, learning capability, managemnt capability, marketing capability, relational capability and technological capability as determinants of SMEs competitive advantage in developing economies.

\section{Research Objectives}

The aims of this study is to evaluates the reliability of measurement items adapted to determine the factors influencing SMEs competitive advantage in developing economies of Africa. Therefore, this study is significant due to the dearth of literature which examined the roles of strategic capabilities such as innovation capability, learning capability, managemnt capability, marketing capability, relational capability and technological capability in enhancing competitve advantage of SMEs firms. Hence, the finding of this study provided a survey measurements which can be used to empirically examine the relationship of strategic capabilities and competitive advantage. Precisely, the study has contribted to the body of existing knowledge on dynamic capabilities theory (DCT) and resource-based view (RBV). The study demonstrated these strategic capabilities as valuable, rare, inimmitable and nonsubstitutable (VRIN) resources and dynamic capabilities capable of improving competitive advatage of SMEs firms. Consequently, the findings of this study provided numerous valuable inputs to managers and policy makers for strategic decisions concerning competititive advantage of SMEs in developing economies.

\section{Methodology}

The study adopted a quantitative research design using questionnaire to collect the data. Unequivocally, subjective items were used on the questionnaire to measure all the variables. The owner/managers perceptions on the items were measured on a five-point Likert scale. Precisely, competitive advantage were measured with 10 items adapted from Ibrabim, (2016). Similarly, 8 items adapted from Juho-Petteri, et al., (2010) were used to measure innovation capability, whereas learning capability was measured with 7 items from Hailekiros and Renyong, (2016). Furthermore, 8 items and 11 items measuring management capability and technological capability were adapted from Halac, (2015). Marketing capability on the other hand was measured with 4 items by Kamboj and Rahman, (2017). The 9 items used to measure relational capability was adapted from Pham, et al, (2017). Personal delivery and collection method was used to administer the questionnaire randomly on 150 SMEs owner/managers in Yobe state Nigeria. Consequently, 84 questionnaires were retrieved; 


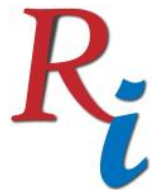

\section{Asia Proceedings of Social Sciences \\ (APSS) \\ www.readersinsight.net/APSS}

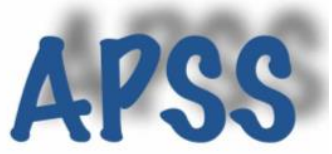

however, 3 were not properly filled, thus discarded. Accordingly, 81 valid questionnaires were keyed into statistical package for social science (SPSS 24) for the analysis.

\section{Results}

The results of reliability test show that the entire variables under study have satisfied the minimum requirement of 0.60 established for Cronbach's alpha (Hair, et al., 2017 Creswell, 2012). Explicitly, competitive advantage has 0.85, innovation capability 0.93, learning capability 0.70 , management capability 0.92 , marketing capability 0.90 , relational capability 0.71 and technological capability has 0.92 as Cronbach's alpha value.

\section{Findings}

The study established that; the items adapted to measure competitive advantage, innovation capability, learning capability, management capability, marketing capability, relational capability, and technological capability are reliable to be use as survey instrument in developing economies of Africa to empirically examine the role of strategic capabilities in enhancing SMEs competitive advantage.

\section{References}

Creswell, J.W., 2012. Educational Research: Planning, Conducting, and Evaluating Quantitative and Qualitative Research, 4th ed, Educational Research.

Devlin, J., Ennew, C.T., 1997. Understanding competitive advantage in retail financial services. Int. J. Bank Mark. 15, 73-82.

Hailekiros, G.S., Renyong, H., 2016. The effect of organizational learning capability on firm performance : Mediated by technological innovation capability. Eur. J. Bus. Manag. 8, 8795.

Hair, J.F., Hult, T.M.., Ringle, C.M., Sarstedt, M., 2017. A Primer on Partial Least Squares Structural Equation Modeling (PLS-SEM), Second Edi. ed, Development. Sage publications., Los Angeles London New Delhi Singapore Washington DC Melbourne.

Halac, D.S., 2015. Multidimensional construct of technology orientation. Soc. Behav. Sci. 195, 10571065.

Hall, J., Wagner, M., 2012. Editorial: The challenges and opportunities of sustainable development for entrepreneurship and small business. J. Small Bus. Entrep. 25, 409-416.

Ibrabim, N.M.N., 2016. Moderating and Mediating Roles of Human Capital and Competitive Advantage on Entrepreneurial Orientation, Social Network, and Performance of SMES in Nigeria. Universiti Utara Malaysia.

Juho-Petteri, H., Jaakkola, M., Frösén, J., Tikkanen, H., Jaakko Aspara, P.M., 2010. Market Orientation, Innovation Capability and Business Performance: Insights From Different Phases of the Business Cycle. J. Mark. Res. 1-10.

Kamboj, S., Rahman, Z., 2017. Market orientation, marketing capabilities and sustainable innovation: The mediating role of sustainable consumption and competitive advantage. Manag. Res. Rev. 40, 698-724.

Ma, H., 2004. Toward global competitive advantage: Creation, competition, cooperation, and cooption. JManagement Decis. 42, 907-924.

Pham, T.S.H., Monkhouse, L. Le, Barnes, B.R., 2017. The influence of relational capability and marketing capabilities on the export performance of emerging market firms. Int. Mark. Rev. 34, 606-628.

Teece, D., 1992. Competition, Cooperation, and Innovation. Organizational Arragements for Regimes of Rapid Technological Progress. J. Econ. Behav. Organ. 18, 447-474. 